\title{
The influence of education level and job type on work-related travel patterns within rural metro-adjacent regions: The case of Castilla-La Mancha, Spain
}

\author{
Inmaculada Mohino \\ Department of City and Regional Planning \\ Universidad Politécnica de Madrid \\ Inmaculada.mohino@upm.es
}

\section{Eloy Solis}

University of Castilla La Mancha

eloy.solis@uclm.es

\author{
José M. Urena \\ University of Castilla La Mancha \\ josemaria.urena@uclm.es
}

\begin{abstract}
Contemporary functional linkages and their relationships with the underlying settlement structure have been widely explored within polycentric urban configurations, but little attention has been paid to their adjacent rural regions. This paper examines the spatial patterns of commuting versus business travel in rural metro-adjacent regions to explain their reconfigured urban structures. These travel patterns are compared by considering workers' education levels and occupations to investigate how rural metro-adjacent regions offer different opportunities for highly and non-highly skilled workers. Based on two surveys conducted by the authors in 2012, this work focuses on Castilla-La Mancha (CLM, Spain), a rural region under the influence of Madrid. The empirical results demonstrate the effectiveness of considering different functional linkages when explaining the underlying urban network. In particular, the results reinforce the idea of consolidating the polycentric spatial organization of urban centers in CLM, although this concentration is greater for commuting travel purposes and for highly skilled professionals. Conversely, the openness of CLM to other Spanish regions (including the adjacent metropolitan region) is greater for business travel than for commuting. The results also illustrate that the level of engagement, both in commuting and in business travel, increases with education. Finally, the results show that business travel occurs over longer distances than commuting does for all workers residing in rural metro-adjacent regions, regardless of education.
\end{abstract}

\section{Article history:}

Received: April 22, 2018

Received in revised form:

August 12, 2018

Accepted: September 23, 2018

Available online: January 28,

2019

\section{Introduction}

Although migration has emerged as a noteworthy issue within social science research (Milbourne \& Kitchen, 2014), some scholars have questioned it within contemporary society. They argue that, due to communication and transportation improvements, "temporary" movements (commuting, intra-com-

Copyright 2019 Inmaculada Mohino, José M. Urena \& Eloy Solis

http://dx.doi.org/10.5198/jtlu.2019.1219

ISSN: 1938-7849 | Licensed under the Creative Commons Attribution - Noncommercial License 4.0

The Journal of Transport and Land Use is the official journal of the World Society for Transport and Land Use (WSTLUR) and is published and sponsored by the University of Minnesota Center for Transportation Studies. 
pany transfers, business trips or virtual contacts) have become more common and have replaced migration (Green Hogarth, \& Shackelton, 1999), producing decreases in depopulation in some areas, mainly rural areas (Sandow, 2008). These changes accompany the transformation of monocentric urban structures into more polycentric ones (Derudder, Hoyer, Taylor, \& Witlox, 2012; Kloosterman \& Musterd, 2001), resulting in significant spatial re-organization of functional linkages (Florida, Gulden, \& Mellander, 2008; Hall \& Pain, 2006) with regard to destinations, ${ }^{1}$ times and distances ${ }^{2}$ (Jones, 2013; Millard-Bell \& Schipper, 2011; Sassen, 1999).

In this context of an increasingly mobile workforce (Kakihara \& Sørensen, 2004) and emerging polycentric urban structures (Champion, 2001), the contributions of this paper are threefold.

- First, regarding the scale of analysis, we provide a more critical understanding of contemporary/ short-term mobilities in a rural region adjacent to a metropolitan one (what we call a rural metro-adjacent region ${ }^{3}$, according to Mohino, Solis, and Ureña (2017)). Although mobilities from, to and across the rural space have long represented a key research topic due to opportunities for rural development (Bijker et al., 2015; Kilpatrick, 2011 ; Stockdale, 2006), "outside major agglomerations, the understanding of the multidirectional nature of commuting patterns is more limited" (Harris, Alasia, \& Bollman, 2008, p. 13). Only a few recent studies have emphasized travel patterns in rural areas located beyond metropolitan centers (Piorr, Ravetz, \& Tosics, 2011; Ravetz, Fertner, \& Sick-Nielsen, 2013; Mohino et al., 2017). Thus, it is necessary to engage more critically with rural regions ${ }^{4}$ adjacent to emerging polycentric urban regions due to the multiple transformations that have occurred in recent years. Although Mohino et al. (2017) focused only on commuting flows, that study identified that these regions are a) becoming hybrid territories, changing from predominantly rural territories into areas that exhibit mixed rural-metropolitan behaviors; b) increasingly influenced by metropolitan overflows, which are predominantly integrating non-central municipalities; c) transforming their urban spatial structures from leaderless models to incipient, polycentric ones; and d) experiencing a commuting reconfiguration towards multidirectional patterns.

- Second, we contribute in terms of the travel purposes considered: commuting vs business travel. Despite the globalization era, travel purposes other than commuting occupy a crucial role and constitute a main component of daily mobility, but only a few studies have considered less frequent work-related (i.e., business trips) or non-work-related (i.e., shopping, health or leisure) travel (Aguilera \& Proulhac, 2015; Boarnet \& Sarmiento, 1998; Schwanen, Dieleman, \&

\footnotetext{
${ }^{1}$ Growing complexity and dispersion in flow networks, diminishing in percentage terms, travel in the direction of the metropolitan center (Aguiléra, Massot, \& Proulhac, 2009; Clark \& Kuijpers-Linde, 1994; Lowe, 1998).

${ }^{2}$ European studies have concluded that longer distances have resulted from polycentric urban models (Lyons \& Chatterjee, 2008; Renkow \& Hower, 2000).

${ }^{3}$ According to the OECD, a "predominantly rural region" is defined as one with more than $50 \%$ of its population residing in rural communities, whereas a "rural community" has a population density of less than 150 persons $/ \mathrm{km}^{2}$ (OECD, 2011). A distinction has also been made with regard to the distance from metropolitan centers: "rural metro-adjacent regions," "rural non-metro-adjacent regions" and "rural northern regions" (Alasia \& Rothwell, 2003). In contrast to the traditional term "ruralurban regions," which includes the urban and peri-urban areas as well as the rural hinterland, the term "rural metro-adjacent region" (Mohino et al., 2017) refers only to rural territories adjacent to a metropolitan region and that are also an administrative region (NUTS-2, according to the European terminology). Some European examples of rural metro-adjacent regions are the following NUTS-2: ES41- Castilla y León or ES42- Castilla-La Mancha (in Spain, adjacent to the Madrid Metropolitan Region); FR21- Champagne-Ardenne, FR24 - Center or FR26 - Bourgogne (in France, adjacent to the Paris Metropolitan Area); the IE01 - Border, Midland and Western (in Ireland, adjacent to the Dublin Metropolitan Area); FI1C - Etelä-Suomi (in Finland, adjacent to the Helsinki Metropolitan Area); PL61 - Kujawsko-pomorskie and PL62 - Warmińsko-mazurskie (in Poland, adjacent to the Warsaw Metropolitan Area); ITI2 - Umbria and ITF1 - Abruzzo, the NUTS2 (in Italy, adjacent to the Rome Metropolitan Area)

${ }^{4}$ Within the limits of this paper, a conceptual distinction is made between the terms "area" and "region," applying the second term to administrative regions, that is, to territorial units (with definitely marked boundaries) into which a country is divided.
} 
Dijst, 2001). According to Burger, Meijers, and van Oort (2014), different travel purposes may lead to different spatial organizations, indicating that a region may appear to be spatially integrated based on the analysis of one type of travel but loosely connected based on the analysis of another. In this regard, this paper contributes an in-depth exploration of the spatial organization of other forms of work-related travel, such as business flows, ${ }^{5}$ compared with the commuting form.

- Third, this study contributes in terms of the individuals under consideration: professionals with different education levels. Recent research has supported the idea that mobility patterns, even when considering a single type of flow, are influenced not only by different residences and workplace locations but also by workers' socioeconomic features (Punpuing, 1993; Prashker, 2008; Kim, Sang, Chun, \& Lee, 2012), households and family structures (Giuliano \& Gillespie, 1997) and the socio-demographic characteristics of the population (Titheridge \& Hall, 2006; van de Coevering, \& Schwanen, 2006; Albertos, Noguera, Pitarch, \& Salom, 2007). Although many scholars have paid attention to gender differences in commuting (White, 1986; Gordon, Kumar, \& Richardson, 1989; Blumen, 1994), few have focused on educational levels, income or occupational profiles (Harsman \& Quigley, 1998; Jara-Díaz \& Videla, 1989). Addressing this individual heterogeneity is important "as networks of flows are built up by heterogeneous individual and group behavior, and structural changes and policies that benefit one group may harm another" (Burger et al., 2014).

In summary, the aims of this broader approach that covers wider and farther territories from metropolises (rural metro-adjacent region) are twofold: first, to understand possible differences in the spatial organizations of commuting and business travel in relation to the underlying urban configurations, which have been previously underexplored in the literature; second, to explore the influence of educational level and occupation on the aforementioned work-related relationships. In doing so, this research focuses on central Spain, specifically on the Castilla-La Mancha (hereinafter CLM) administrative region (adjacent to the Madrilenian region), towards which metropolitan processes have already begun to have spillover effects (Mohino, Ureña, \& Solis, 2016; Mohino et al. 2017). Information on commuting and business travel collected from two original mobility surveys provided the data to support this research. The first survey addressed a sample of regional households, and the second addressed three university graduate types of professionals (architects, civil engineers and lawyers).

The remainder of this paper is organized into the following four sections: a) a literature review on functional relationship analyses and research hypotheses; b) the case study, data sources and methodological approach; c) a comparative discussion of commuting and business travel patterns for the CLM region; and d) a summary/debate of the conclusions.

\section{$2 \quad$ Literature review}

\subsection{The need to explore rural metro-adjacent regions' work-related travel patterns}

Improved communication and transportation systems together with the increase in multilocational firms have led to a conspicuous scale shift of metropolitan systems covering the wider context of the "rural-urban region" (the "peri-urban" area and rural hinterland) (Piorr et al., 2011). This shift has also resulted in the functional integration of surrounding, but historically autonomous, small/medium-sized cities ("Historic Administrative Cities") into the metropolitan network (Solis, Mohino, \&

\footnotetext{
${ }^{5}$ Within the limits of this paper, business travel comprises work-related trips to an irregular place of work. This definition is similar to that suggested by Aguilera (2008) — "work-related travel to an irregular place of work" — such as visiting a client, participating in a conference or attending a meeting. This paper considers only business trips to a municipality other than the place of residence.
} 
Ureña, 2014). As a result of these new spatial configurations, urban systems have witnessed considerable functional transformations; multidirectional and spatially discontinuous functional relations between the metropolitan center and its wider surrounding territory and within these more distant areas have acquired greater relevance, whereas hierarchical and unidirectional relations towards the metropolitan center have diminished in percentage terms (de Goei, Burger, van Oort, \& Kitson, 2010; Parr, 2005).

Nevertheless, the literature on functional relations has focused mainly on large/global cities and urban areas/city regions (Burger, de Goei, van der Laan, \& Huisman, 2011; Dieleman \& Faludi, 1998) and has paid little attention to rural regions. Therefore, there is a need to explore the relationship between urban structures and mobility patterns within rural regions due to the multiple transformations that they have faced, which increasingly blur the traditional dichotomy between the rural and the urban (Ortiz-Guerrero, 2013). These changes have long represented a significant research theme within rural studies, and many researchers have mapped people's relocations into and out of rural places (Milbourne, 2007). However, beyond this special concern regarding migration (Bijker et al., 2015; Findlay, Stockdale, Findlay, \& Short, 2001; Stockdale, 2006), there is a considerable lack of understanding about rural contemporary mobilities, which constitute an extremely interesting case associated with increasing proportions of people deciding to remain local and travelling every day to access (more distant) opportunities (Malmberg, 1997; Milbourne \& Kitchen, 2014).

Overall, rural metro-adjacent regions (Mohino et al., 2017), which cover a broader territory than that of the rural-urban region and towards which emerging polycentric urban regions have started to spread their influence, are a particular and immensely interesting case: first, to understand the interaction capabilities (in terms of emitting or attracting flows) of these rural metro-adjacent regions (in contrast to urban regions); second, to delineate dependencies with the metropolitan region or other external territories (what we call "openness") or with other areas within the same rural region (what we call "intraregional cohesion").

\subsection{The relevance of travel purposes and individual socioeconomic features in understanding functional linkages}

Despite the need to consider different travel purposes (Burger et al., 2014) when analyzing functional interactions, most studies have concentrated on commuting, and only a few have considered less frequent work-related (i.e., business trips) or non-work-related (i.e., shopping, health or leisure) travel (Frändberg \& Vilhelmson, 2011; Limtanakool, Dijst, \& Schwanen, 2007, 2009; Schwanen et al., 2001). This is because commuting has been considered the major daily recurrent form of travel (Hincks \& Wong, 2010), and commuting data are generally the most elaborate, reliable, and relevant interaction information available (Burger et al., 2014). In addition, commuting is one of the major forces of change in rural areas (ESPON, 2006) since, as an alternative to migration, it can give rise to decreases in these areas' depopulation (Sandow, 2008; Sandow \& Westin, 2010).

Travel purposes other than commuting, although still representing a small percentage of daily travel (Aguiléra, 2008; Nelson \& Niles, 2000), have exerted a noteworthy impact on travel growth in the last decades (Ureña \& Muruzábal, 2006). In particular, business travel progressively represents an important type of mobility and an essential component of working days (Beaverstock, Derudder, Faulconbridge, \& Witlox, 2010; Derudder, Devriendt, van Nuffel, \& Witlox, 2010; Lyons, 2013; Mason, 2002; Räsänen, Moberg, Picha, \& Borggren, 2010). This increased number of business relations ${ }^{7}$ is evidenced

\footnotetext{
${ }^{6}$ Regional openness relates to the extent to which the region is connected to external territories. It is defined here as the percentage of the working population residing in the rural metro-adjacent region and traveling to a different region for commuting or business purposes.

${ }^{7}$ This is due to the growing number of multinationals/multiplant businesses with geographically distant units/offices, increasing intra- and inter-firm national/international relations, the improved transport infrastructures, and the relative ease of movement or the growing need to attend conferences, trade shows and courses.
} 
in official statistics regarding international travel (Faulconbridge, Beaverstock, Derudder, \& Witlox, 2009), but less is known about business mobility at the regional and national scales (Jones, 2013). The amount, frequency and geographical patterns of business travel vary depending on the corporation's size, sector and internal/external organization and on workers' socioeconomic features (gender, education level, professional status, hierarchical position, income, household structure, workplace, etc.) (Aguiléra, 2008).

Therefore, since this spatial configuration of functional interactions within rural metro-adjacent regions can vary with regard to the type of functional relation (Burger et al., 2014), further comparative analyses of the spatial organization of commuting and business travel patterns in relation to the underlying urban system are needed to complement the scarce literature on this specific study area. Nevertheless, as some scholars have concluded, differences in these spatial organizations are attributable not only to the geographical mismatches of origin (home) and destination (workplace) with built-up area characteristics (density, diversity and design) (Boarnet \& Sarmiento, 1998; Cervero \& Kockelman, 1997; Sultana, 2004) but also to workers' socioeconomic characteristics (Giuliano \& Gillespie, 1997; Hincks \& Wong, 2010; Prashker, Shifton, \& Hershkovitch-Sarusi, 2008; Titheridge \& Hall, 2006).

In summary, studies of workers' socioeconomic characteristics have shown the following. Regarding gender, women commute shorter distances and spend less time commuting than men do (Manaugh, Miranda-Moreno, \& El-Geneidy, 2010), which could be explained by women's lower salaries and maternal responsibilities (Kim et al., 2012). Other studies have revealed that women tend to commute shorter distances than men do regardless of income (Singell \& Lillydahl, 1986) and occupational status (Gordon et al., 1989; Hanson \& Johnston, 1985). Regarding education, commuters are more highly educated than non-commuters are ${ }^{8}$ (Burger et al., 2014; Huber, 2014; Lee \& McDonald, 2003), and those who are highly educated are more willing than are those with lower education levels to commute longer distances (Harsman \& Quigley, 1998; Trendle \& Siu, 2005). Regarding income, higher wage workers appear to travel longer distances on average ${ }^{9}$ (Dargay \& Stephen, 2012; Naess, 2006). Regarding occupation, administrative and technical employees commute longer distances than service workers do (Giuliano \& Small, 1993). However, other studies have not found a significant influence of income and educational attainment on commuting behavior (Antipova et al., 2011). In addition, despite the greater attention paid to gender compared to other socio-demographic variables, variations in the number of flows and the average commuting distances have been found to be higher based on occupation than based on gender (Kim et al., 2012).

Bearing in mind that both the mobility levels and the distances covered to reach work as well as the various amenities in rural or low-density areas are greater than those in urban regions (Hincks \& Wong, 2010; Mohino et al., 2017) and that travel and long-distance commuting are positively correlated with education level, the extent to which these two issues have multiplying effects remains unclear.

\subsection{Research hypotheses}

Emerging from this literature review and the aforementioned research gaps, three research hypotheses drive the present study on work-related functional linkages within rural metro-adjacent regions. The first hypothesis posits that a polycentric urban structure is emerging in these rural regions, concentrating a large percentage of the working population. This becomes more relevant with increasing education, leading to greater intra-regional cohesion than with the traditional metropolitan dependence. The second hypothesis proposes that highly skilled professionals (hereinafter HSPs) living in these regions engage

\footnotetext{
${ }^{8}$ Some studies have concluded that more informed household location decisions by better-educated professionals would minimize commuting (Wang, 2001).

${ }_{9}^{9}$ Increased commuting by those with higher educational levels might be justified either by higher income levels (Watts, 2009) or because search areas for jobs are larger (García-Palomares, 2008; Öhman \& Lindgren, 2003).
} 
more in commuting than do non-highly skilled professionals (hereinafter NHSPs) and, on average, are more willing to travel farther distances. Similarly, the third hypothesis posits that HSPs are more willing to engage in business travel and for longer distances for this purpose than NHSPs are.

\section{Study area, data sources and methodological approach}

\subsection{Central Spain as a case study}

This study covers the Spanish administrative region of Castilla-La Mancha (CLM), a rural ${ }^{10}$ region adjacent to the Madrid metropolitan region (Fig. 1). The relevance of focusing on CLM is that it is one of the only two Spanish regions that are characterized simultaneously by their rural character and by their adjacency to a metropolitan area. Although scholars have analyzed mobility in central Spain, most of these studies have focused on the Madrid region (Gallo, Garrido, \& Vivar, 2010; García-Palomares, 2010) and on commuting travel (Mohino et al., 2017; Pillet et al., 2014; Solis, Ureña, \& Ruiz-Apilánez, 2012; Solis et al., 2014).

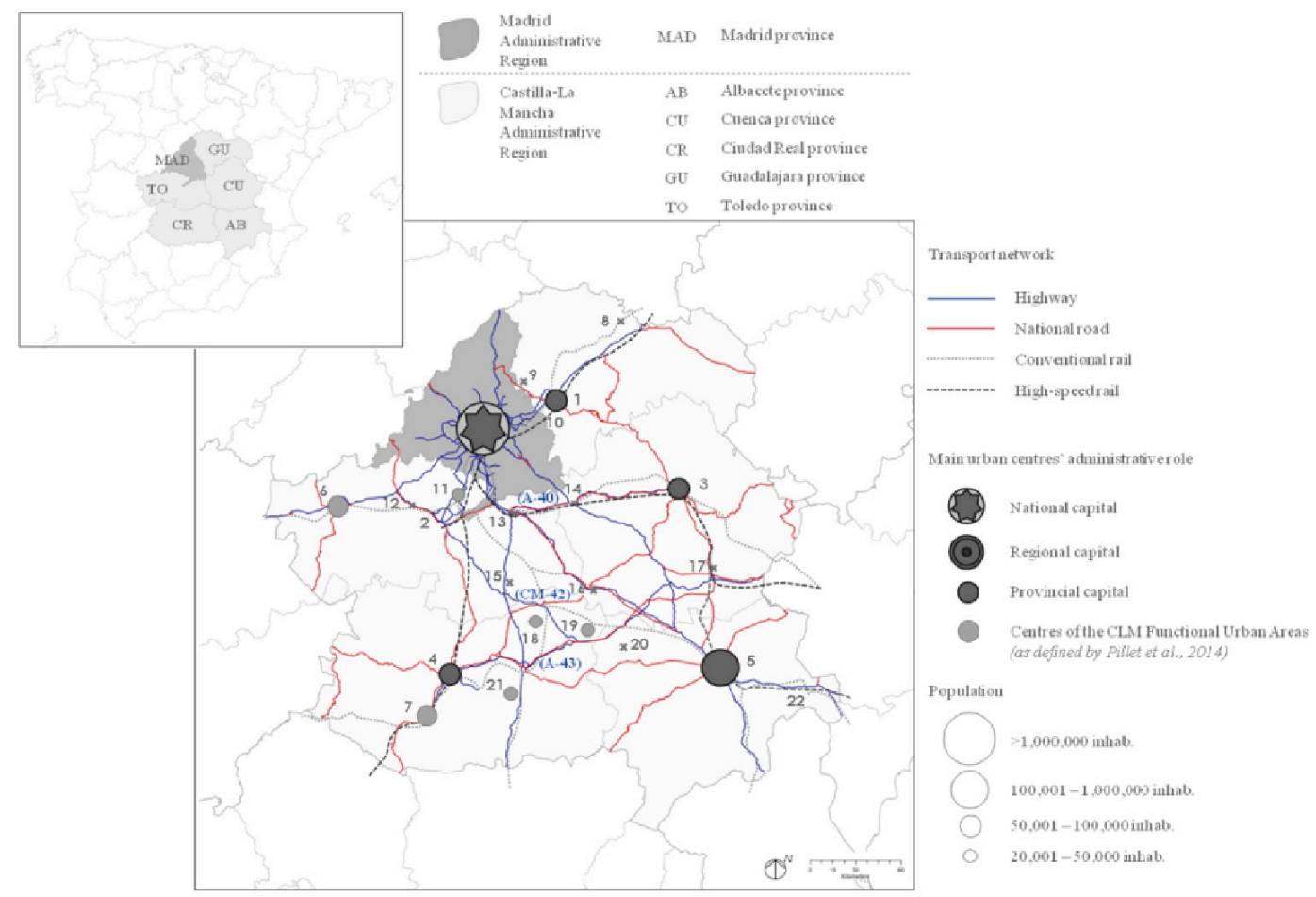

Figure 1. The Castilla-La Mancha Administrative region as a case study: main urban (municipalities with more that 20,000 inhab.) and transport networks. Sources: CNIG, INE, authors

NOTE: The numbers refer to the municipalities where the household mobility surveys were coonducted (in bild, the even FUA centres identified by Pillet etal. (2014): (1) Guadalajara; (2) Toledo; (3) Cuenca; (4) Ciudad Real; (5) Albacete; (6) talavera de la Reina; (7) Puertollano; (8) Siguenza; (9) el Casat; (10) Azuqueca de Henares; (11) Illescas; (12) Torrijos; (13) Ocana; (14) Tarancon; (15) Madridejos; (16) Mota del Cuervo; (17) Motilla del Palancar; (18) Alcazar de San Juan; (19) Tomelloso; (20) Villarrobledo; (21) Valdepenas; (22) Almansa. Coverslely, the surveys addressed to the three professional associates were e-mailed to all of their members.

${ }^{10}$ In 2011, the OECD defines the five provinces that comprise the CLM region as it is "predominantly rural" (see:http://ec.europa.eu/eurostat/statistics-explained/index.php/File:Urban-rural_typology_of_NUTS3_regions_including_ remoteness.PNG). 
CLM, located between $40 \mathrm{~km}$ and $300 \mathrm{~km}$ from the municipality of Madrid, is a European "Objective 1 region' (OECD) with low population density (26.4 inhab/ $\mathrm{km}^{2}$ in 2012) that predominantly comprises municipalities of fewer than 2,000 inhabitants (78.8\% in 2012). However, half of the population (55.6\% in 2012) is concentrated in 39 municipalities with more than 10,000 inhabitants. Only seven municipalities have between 50,000 and 175,000 inhabitants: the five provincial capitals; Talavera de la Reina; and Puertollano (see Fig. 1). This particular urban structure ${ }^{11}$, which is not relevant in terms of population size and is irregularly distributed throughout the regional territory, has traditionally characterized the configuration of CLM. Nevertheless, since the 1980s, due to both the administrative decentralization ${ }^{12}$ led by state rescaling and the recent transport investments (diminishing the traditional "passing-through" character of its infrastructures - Mohino et al. (2016)), CLM witnessed considerable population growth and a centralization process towards the five capital cities (motivated by the location of public and administrative services in these cities as a result of the rescaling of Spain). Recent studies have accounted for an incipient CLM polycentric urban structure. For example, Pillet et al. (2014) identified 10 Functional Urban Areas (FUAs) organized by 11 FUA centers, which constitute the main CLM urban structure, and another 15 Dependent Areas (DAs) on the 10 FUAs (organized by 15 DA sub-centers).

Both the CLM population and its mobility patterns have changed over the last three decades ${ }^{13}$ (INE, 1981; 2011), characterized by a) a large increase in out-commuting, from $9.7 \%$ in 1981 to $31.6 \%$ in 2011, which is larger than in other rural regions that are less influenced by metropolitan processes; b) an increase in commuting to the Madrid administrative region, from 20.5\% in 1981 to $32.3 \%$ in 2011; and c) intensified intra-regional cohesion derived from increasing out-commuting among FUA centers, from $4.6 \%$ in 1981 to $10.0 \%$ in 2011 .

\subsection{Sampling and data collection}

Undoubtedly, travel behavior studies often demand huge data and many scholars based their analyses on databases collected by the national, regional, metropolitan or local authorities/governments. Household travel survey data are most frequently used for this purpose (Aguilera \& Proulhac, 2015; Dieleman, Dijst, \& Burghouwt, 2002; Figueroa, Nielsen, \& Siren, 2014; Giuliano \& Dargay, 2006; Limtanakool, Dijst, \& Schwanen et al., 2009; Rouwendal \& Rietveld, 1994; Susilo \& Maat, 2007; van Acker \& Witlox, 2011). For studies focused on commuting, Censuses have been their main source (i.e., Aguiléra, 2005; Champion, Coombes, \& Brown, 2009; Hincks \& Wong, 2010; Mohino et al., 2016; SickNielsen \& Harder Hovgesen, 2008; Titheridge \& Hall, 2006).

\footnotetext{
${ }^{11}$ Traditionally defined as a disorganized, acephalic/leaderless region that lacks functional cohesion and that is conspicuously functionally dependent on Madrid and other Mediterranean urban areas (Cebrián \& Cebrián, 2000)

${ }^{12}$ Processes of population/economic decentralization within the Madrid Region have led to the emergence of new sub-centers and the integration of historic cities into the expanding metropolitan area extending beyond the Madrid Administrative Region (Solis et al., 2012). As a result, functional interrelations have developed from/towards the neighbouring provinces of two different rural metro-adjacent regions (Solis et al., 2014): CLM and Castilla y León.

${ }^{13}$ As a consequence of the transport and urban networks transformations within the Madrid region, in addition to the overall increase in mobility between 1981 and 2011 (INE, 1981, 2011) from 299,668 to 1,297,709, its commuting patterns have been reorganized: a) centripetal flows towards the municipality of Madrid substantially declined from 65.6\% in 1981 to $44.2 \%$ in 2011; b) centrifugal flows from the municipality of Madrid to the rest of the Madrid region increased from 14.1\% in 1981 to $18.5 \%$ in 2011 ; and c) tangential (or periphery-periphery) flows between metropolitan sub-centers increased considerably from $20.3 \%$ in 1981 to $37.3 \%$ in 2011 .
} 
One challenge faced by this research, in addition to the poor quality of official commuting CLM statistics, ${ }^{14}$ is the lack of official CLM statistics for travel purposes other than commuting, particularly for business trips. A region-wide study would involve a huge data collection effort, and after the data collection, a careful investigation of the characteristics of the travel behavior data is also required. As stated by Schofer (2002), apart from being increasingly expensive to undertake, household travel surveys have some problems with response rates, misreporting of travel, the increasing difficulty of conducting computer-assisted telephone interview surveys, the demand for greater spatial coverage of the sample within a region to support micro-level planning along transport corridors and within subareas, etc. Stopher, Greaves, and Xu (2005) also warn that surveys in both small urban and rural areas, are potentially more expensive to conduct than the standard metropolitan HTS and survey sample sizes for these areas are likely to be relatively small (although the desire may still be to produce models for each such geographic grouping). All this means that, in some areas, these detailed databases are not available or updated. This lack of reliable or specific (non-work related travel) information (mainly in rural areas), which has been argued in abundant studies, has forced scholars to use other ways to collect information different than the household travel surveys (such as internet survey techniques as employed by Bernard, Kostelecký, \& Patočková, 2014; Verhoeven, Arentze, Timmermans, \& van der Waerden, 2007, or interview surveys as Brown \& O'Hara, 2003; or Ramli, Oeda, Sumi, \& Matsunaga, 2011; or a combination of both as Sioui, Morency, \& Trapanier, 2013) and to limit their analyses to a few number of surveys and places. Overall, as in many similar mobility studies (see Appendix 1), to collect information about the commuting ${ }^{15}$ and business ${ }^{16}$ travel patterns of the CLM working population, the data were based on two original surveys.

\subsubsection{A mailed paper-and-pencil survey of school-aged CLM households}

Due to the extent and population of CLM, surveying all of the regional households was rejected due to human and economic resource limitations. Alternatively, questionnaires were addressed to a sample of regional households. ${ }^{17}$ The methodology, which was previously shown to have produced revealing conclusions regarding mobility patterns (Garmendia, Ureña, \& Coronado, 2011), consisted of a tree-shaped distribution and collection method with a set of key individuals (direct contacts), who distributed the leaflets to the entire sample. Both high school students and respondents (households) from among lastgrade students were randomly selected from a set of (twenty-two) municipalities ${ }^{18}$ (see Fig. 1). Despite

\footnotetext{
${ }^{14}$ The 2011 Spanish Census has important constraints: a) it only provides information about a sample from each municipality; b) the total number of out-commuting flows is not provided for the smallest municipalities (accounting for approximately twothirds of the CLM municipalities), and there is no clear threshold above which data are publicly available; and c) commuting information is only published for workplaces in municipal types of locations (distinguishing among the same municipality of residence, different municipality within the same province of residence, different province within the same region, other region, other country) and of certain sizes (and not by specific flow destinations).

${ }^{15}$ Commuting travel comprises daily travel between the place of residence and place of work (this paper considers only outcommuters, that is, workers traveling daily for working purposes to a different municipality than that of residence).

${ }^{16}$ Business travel comprises work-related trips to an irregular place of work (this paper considers only business trips to a municipality other than the place of residence).

${ }^{17}$ Travel behavior analyses often require a substantial amount of data. Due to the enormous effort dedicated to the collection and investigation of data in a country-wide study, household travel survey data are most frequently used for this purpose (Giuliano \& Dargay, 2006).

${ }^{18}$ These municipalities, which include the eleven FUA centers identified by Pillet et al. (2014), were selected a) by their geographical location to characterize key regional municipalities homogeneously distributed throughout CLM; b) by their population size and the presence of at least one high school; c) by their positive 1981-2011 demographic dynamics; and d) by their intermediary roles and capability for organizing/articulating adjacent territories.
} 
the possible bias ${ }^{19}$ generated by only considering some of the regional households (school aged), this working population sector has noteworthy mobility levels, and its analysis has already produced accurate, relevant and appropriate results (Brown \& O'Hara, 2003; Garmendia et al., 2011).

Initially establishing an accepted error rate of $1 \%$ and a confidence level of $95 \%$, the minimum sample size for the total school-aged regional households (308,245 in 2012) was 9,314. However, based on Garmendia (2008), the response rate was estimated at approximately $37 \%$; thus, to obtain a representative sample, a total of 25,400 leaflets were randomly distributed to last-grade students in the selected municipalities during April and May 2012. The questionnaire was closed one month after the leaflets were distributed at each high school, by which time 7,332 responses had been received $(29 \%$ response rate). After a debugging process, 6,901 valid answers (27\% response rate) constituted the final data. The sample had a less than $1.5 \%$ margin of error and a confidence level of $95 \%$, constituting a representative sample of all school-aged regional households.

The questionnaire was organized in two sections: first, questions about the household and its head (place of residence, gender, age, number of children in the household, education level, occupation); second, questions about travel to other municipalities, including work-related travel (commuting and business trips undertaken during the previous complete working week) and non-work-related travel (shopping, hiring of consultancy services, visiting of health facilities, leisure) undertaken during the previous complete working week.

\subsubsection{An Internet-based survey directed towards different types of highly skilled professionals residing in CLM}

Most studies of professionals' mobility patterns have examined organizations (private or public) and have placed little or no emphasis on self-employment (independent workers/freelancers). However, over the last two decades, the number of workers independent of a formal organization has considerably increased (Kakihara \& Sørensen, 2004). Thus, instead of focusing on specific corporations ${ }^{20}$, this survey was addressed to three professional sectors (architects - hereinafter ARCH; civil engineers -- hereinafter CE; and lawyers -- hereinafter LAW, residing in CLM) in an attempt to identify differences between workers with university educations. These professional sectors were chosen for two reasons: a) the already assessed large inter-municipal mobility levels for $\mathrm{ARCH}$ and engineers in other Spanish regions (Albertos et al., 2007) and b) their different engagements with the public or private sector (CE have a strong tie with the public sector, whereas the other two professions are usually related more to the private sector). The questionnaire was e-mailed to a randomly selected sample of the CLM architecture, civil engineering and legal professional associations in May 2012, and the electronic application was operative for four weeks. During this month, all of the selected members received three e-mail reminders from their professional associations. Establishing an accepted error rate of 5\% and a confidence level of 95\%, the sample sizes were 127 professionals for the ARCH sector, 174 for the CE sector and 116 for the LAW sector. Past studies have supported data collection following similar methodologies.

\footnotetext{
${ }^{19}$ Instead of this procedure, we could have used landline phone lists of regional households (Pinjari, Pendyala, Bhat, \& Waddell, 2007), but this step would have also led to bias, and the results would have been representative only of those with a landline. In addition, because in-person interviews are costly, the sample sizes would have been smaller if the survey were conducted by telephone (Haselkorn, Spyridakis, Conquest, \& Barfield, 1989).

${ }^{20}$ The need for specific data has also limited previous research in its analyses to a set of firms (such as Hermelin \& Trygg, 2012), to some professional sectors (e.g., Brown \& O’Hara, 2003; Faulconbridge et al., 2009; Gustafson, 2012; Kilpatrick, Johns, Vitartas, \& Homisan, 2011) or to users of a specific transportation mode (e.g., Martínez-García, Ferrer-Rosell, \& Coenders, 2012; Denstadli, Julsrud, \& Hjorthol, 2012). Instead of focusing on specific corporations, we decided to address our survey to three professional sectors since, during the last two decades, the number of workers independent of a formal organization has considerably increased (Kakihara \& Sørensen, 2004).
} 
This questionnaire included questions about a) the surveyed professionals (gender, age, municipality of residence) and the company for which they worked (freelance or contractual basis, public and/ or private sector, size in terms of the number of offices, location of the headquarters); b) the regular workplace municipality and the transportation mode used to access it; and c) the business travel destinations during the previous complete working week. Each relation was characterized as intra- or inter-firm by the transportation mode used and its frequency (annual, monthly, weekly, twice or more per week). Each respondent could report up to eight different business trips.

\begin{tabular}{|c|c|c|c|c|c|}
\hline \multirow{2}{*}{ Data source } & \multirow{2}{*}{$\begin{array}{c}\text { Type of } \\
\text { individual }\end{array}$} & \multicolumn{2}{|c|}{ Functional linkage } & \multirow{2}{*}{$\begin{array}{r}\text { Type of } \\
\text { analysis }\end{array}$} & \multirow{2}{*}{$\begin{array}{l}\text { Comparison } \\
\text { (in terms of) }\end{array}$} \\
\hline & & Commuting & Business & & \\
\hline \multirow{2}{*}{$\begin{array}{l}\text { Survey 1: } \\
\text { regional } \\
\text { households }\end{array}$} & NHSP & $\checkmark$ & $\checkmark$ & \multirow{2}{*}{$\begin{array}{l}\text { Influence of } \\
\text { education }\end{array}$} & \multirow{5}{*}{$\begin{array}{l}\text { 1. Urban spatial configuration (Fig. 3): } \\
\text { residential location, regular workplace } \\
\text { concentration, business destinations } \\
\text { 2. Level of engagement } \\
\text { 3. Covered distance }\end{array}$} \\
\hline & HSP & $\checkmark$ & $\checkmark$ & & \\
\hline \multirow{3}{*}{$\begin{array}{l}\text { Survey 2: } \\
\text { highly skilled } \\
\text { professionals }\end{array}$} & ARCH & $\checkmark$ & $\checkmark$ & \multirow{3}{*}{$\begin{array}{l}\text { Influence of } \\
\text { occupation } \\
\text { (job type) }\end{array}$} & \\
\hline & CE & $\checkmark$ & $\checkmark$ & & \\
\hline & LAW & $\checkmark$ & $\checkmark$ & & \\
\hline
\end{tabular}

NHSP: Non-highly skilled professsionals (without university education); HSP: Highly skilled professionsals (without university education); ARCH: Architects; CE: Civil engineers; LAW: Lawyers

Figure 2. Data processing methodology

\subsection{Collected data processing methodology}

In both surveys (school-aged regional households and HSPs), although individuals were the sample units, their work trips were the basic unit of our analysis. A double comparison was undertaken (Fig. 2): first, in terms of educational level (between HSPs and NHSPs, using data collected from the first survey); second, in terms of job type (among the three different types of HSPs considered, using data collected from the second survey). This comparison was performed by assessing a) the level of engagement in commuting and business travel ${ }^{21}$ and b) the covered (geographical) distances. Moreover, to understand the interaction capabilities (in terms of emitting or attracting flows) of these rural metro-adjacent regions and to delineate dependencies with the metropolitan region ("metropolitan integration"), with other external territories ("regional openness") or with other areas within the same rural region ("intraregional cohesion"), residential and job location (regular workplace) concentrations as well as main business destinations were identified. This step allowed us to characterize the regional urban structure in terms of the degree of interaction (see Fig. 3). To determine whether differences between education levels and job type were statistically significant, different tests were performed in IBM SPSS Statistics software, version 23.0 (the chi-square tests, the Mann-Whitney U test and the ANOVA).

\footnotetext{
${ }^{21}$ The comparison is feasible since questions were asked in the same manner in both surveys. In terms of commuting, the respondents indicated their municipality of residence and municipality of work. In terms of business, the respondents completed a diary with all of the trips undertaken for business purposes during the previous complete working week.
} 


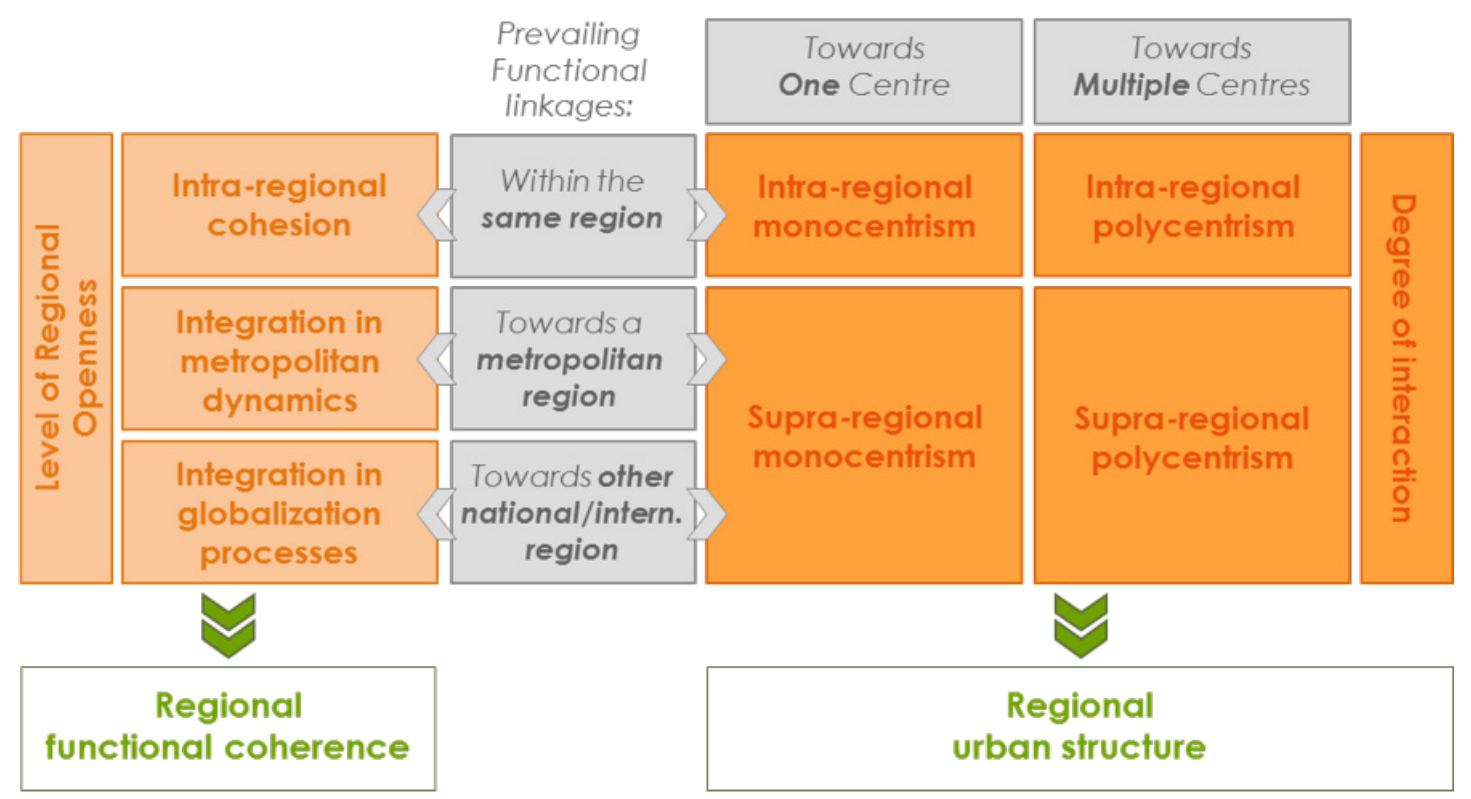

Figure 3. Regional urban structure based on job/business-location concentrations. Source: authors

\section{$4 \quad$ Findings}

\subsection{Residential concentration}

As previously mentioned, to understand interaction capabilities and to detect the main centralities of these rural metro-adjacent regions, residential concentrations were identified. On the one hand, according to the surveys conducted by the authors in 2012, statistically significant differences in the residence concentration could be identified with regard to education (see Table 1): whereas $49.5 \%$ of the NHSP in 2012 resided in the eleven CLM FUA centers (Fig. 1), this figure increased to 66.4\% for HSP. On the other hand, no statistically significant differences (see Table 1) were found in the residence concentration among HSPs with regard to occupation (among lawyers, architects and civil engineers).

These results are in accordance with previous studies concluding that in rural metro-adjacent regions, differences in residence location were found when considering education levels; that is, higher proportions of university-educated workers' residences were concentrated in the main (central) cities (Aguiléra et al., 2009; Russo, Teschi, Reggiani, \& Nijkamp, 2014). Moreover, this relevant concentration of residential locations in FUA centers, which is greater for HSPs, points to the consolidation of the CLM main urban structure as a set of centralities distributed across the territory (as concluded by Mohino et al., 2017, and Pillet et al., 2014). 
Table 1. Influence of education and occupation on housing and labour markets (residential, regular workplaces and non-regular workplaces concentration) and on communiting and bussiness travel patterns (level of engagement and covered distances). Summary of the results obtained from the statustical tests. Source: authors

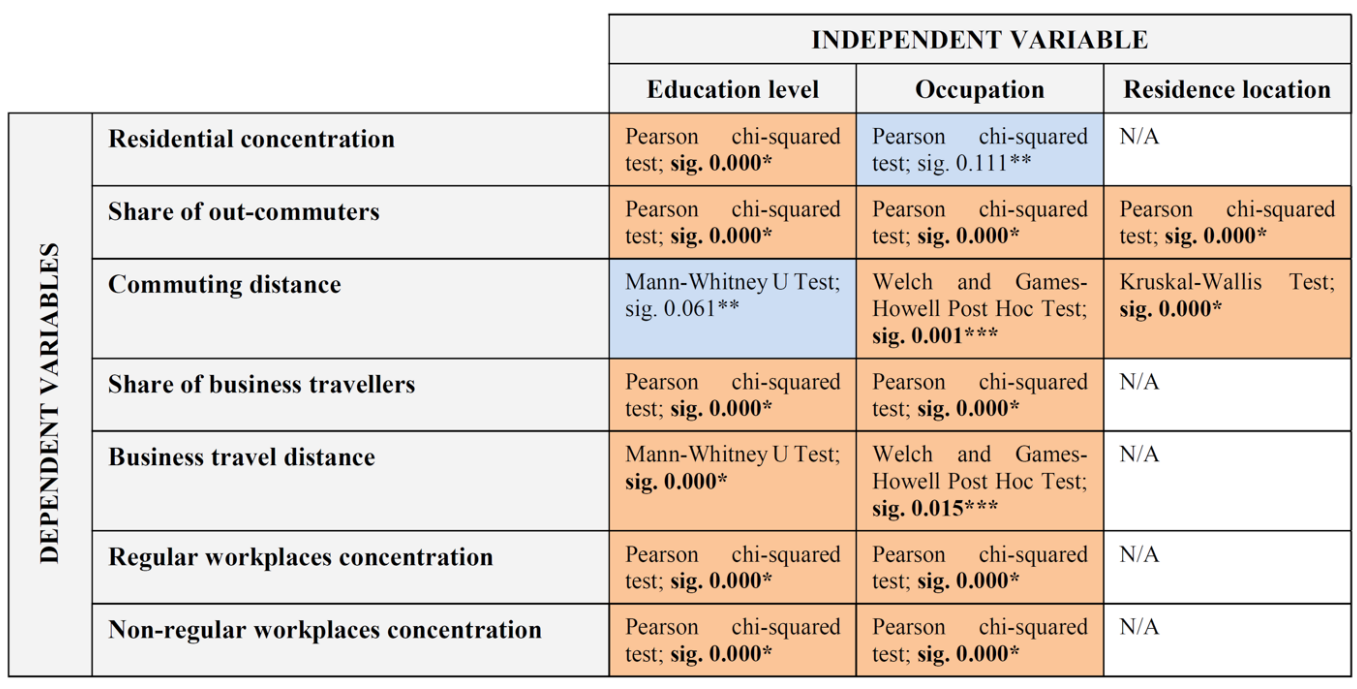

* There are significant differences between the two variables

** There are not significant differences between the two variables

*** There are significant differences between the two variables, at least between two of the groups

N/A: not analysed

\subsection{Labor commuting patterns}

Scholars have found that sensitivity to distance in general decreases as education level increases. This section explores the applicability of this conclusion to rural metro-adjacent region residents. Thus, the second step of this paper compares commuting travel patterns (first between HSPs and NHSPs and second for HSPs among CE, LAW and $\mathrm{ARCH}$ ) in terms of the level of engagement in commuting travel (share of out-commuters) and travelled distances

\subsubsection{Share of out-commuters}

Similar to the previous literature on urban regions, Punpuing (1993) concluded that more educated workers are more likely than others to use commuting as a complement to residential mobility. Statistically significant differences were found in the share of out-commuters (level of engagement in commuting travel) with regard to education (see Table 1): a greater percentage of HSPs than NHSPs commuted daily to different municipalities (i.e., 23.9\% of NHSPs were out-commuters, whereas this proportion was $31.1 \%$ for HSPs), perhaps due to the often better-paid jobs for more highly educated professionals, which can compensate for commuting costs.

This outcome of a greater level of engagement in commuting travel, together with the noteworthy residential concentration of HSPs in the main CLM centralities, indicates that despite the possibility of decentralization offered by new technologies, for HSP, workplaces are not the main factor in determining residence location. More importance is placed on certain urban amenities and quality of life or to the need for face-to-face contact (Grimes, 2000; van Winden, van den Berg, \& Pol, 2007). 
However, both education level and occupation had a relevant impact on out-commuting. Statistically significant differences were also found among the three surveyed professions (see Table 1): CE were more mobile ( $40.7 \%$ commuted to another municipality) than ARCH and LAW (respectively, $13.9 \%$ and $17.3 \%$ were out-commuters). One interpretation of this finding is that the architecture and legal labor markets might be more local and have more freelance ${ }^{22}$ work (more than $85 \%$ ) compared to CE (21.8\%). Former professionals might decide to settle down in the same municipality as their firms to be established near potential clients (who are those travelling to contract a service), thus minimizing their need for commuting. The civil engineering labor market expands to wider territories; therefore, corporations are located in a limited number of cities, ensuring important (global) accessibility levels. Another explanation could be the relevance of the public sector (see Table 2) in this labor market (31.4\% of CE, in contrast to $5.2 \%$ of LAW and $11.0 \%$ of ARCH, work for this sector), which concentrates its central administrations in the main urban centers (provincial capitals).

Table 2. Highly skilled professionals employed in the private and public service sectors. Source: 2012 authors' surveys

\begin{tabular}{lccc} 
& \multicolumn{3}{c}{ Sector } \\
& Public & Private & N/A \\
\hline CE (residing in CLM) & $\mathbf{3 1 . 4 \%}$ & $66.7 \%$ & $1.9 \%$ \\
LAW (residing in CLM) & $5.2 \%$ & $\mathbf{8 0 . 2 \%}$ & $14.7 \%$ \\
ARCH (residing in CLM) & $11.0 \%$ & $\mathbf{7 6 . 4 \%}$ & $12.6 \%$ \\
\hline
\end{tabular}

\subsubsection{Commuting distance}

Regardless of education, commuting travel patterns in CLM can be characterized, for the Spanish context, as short-distance ${ }^{23}$ patterns: the mean commuting distance is $50.4 \mathrm{~km}$ for HSPs and $43.3 \mathrm{~km}$ for NHSPs. This finding is in accordance with previous studies focused on urban areas, demonstrating that university-educated workers are more willing to overcome, on average, greater distances (higher education often leads to better-paid jobs, which can compensate for commuting costs). However, the MannWhitney $U$ test revealed that these differences in commuting distance regarding education were not statistically significant (similar conclusions can be seen in the corresponding box plots -see Table 1).

Moreover, the longer whisker on the upper box plot side suggests that there might be greater variance in commuting distances among the greater values since there is a greater distance from the 3rd quartile to the upper extreme than from the median to the 3rd quartile. Thus, in addition to the average commuting distance, which provides an insightful description of regional commuting patterns, it is necessary to evaluate the dispersion from the average and the number of commutes at different travel distances (see Fig. 4). Although, on average, commutes can be characterized as short-distance trips, Fig. 4 clearly shows that important proportions of commutes are long distance (approximately $40 \%$ of both HSPs and NHSPs commuted distances longer than the 50-km threshold).

\footnotetext{
${ }^{22}$ Since there are no available data regarding CLM freelance proportions for highly skilled professionals, these figures have been obtained from the survey conducted by the authors.

${ }^{23}$ Short- and long-distance trips have been defined in the literature, although without any consensus regarding the threshold used. Recently, Limtanakool et al. (2005) chose $50 \mathrm{~km}$ for the characterization of trips regarding the travel distance. In Spain, according to the MOVILIA 2006/2007 survey, 64\% of work-related travel covered distances of less than $50 \mathrm{~km}$, and only 13\% were trips longer than $100 \mathrm{~km}$. Thus, in this study, short-distance trips are defined as those shorter than $50 \mathrm{~km}$ (one way).
} 


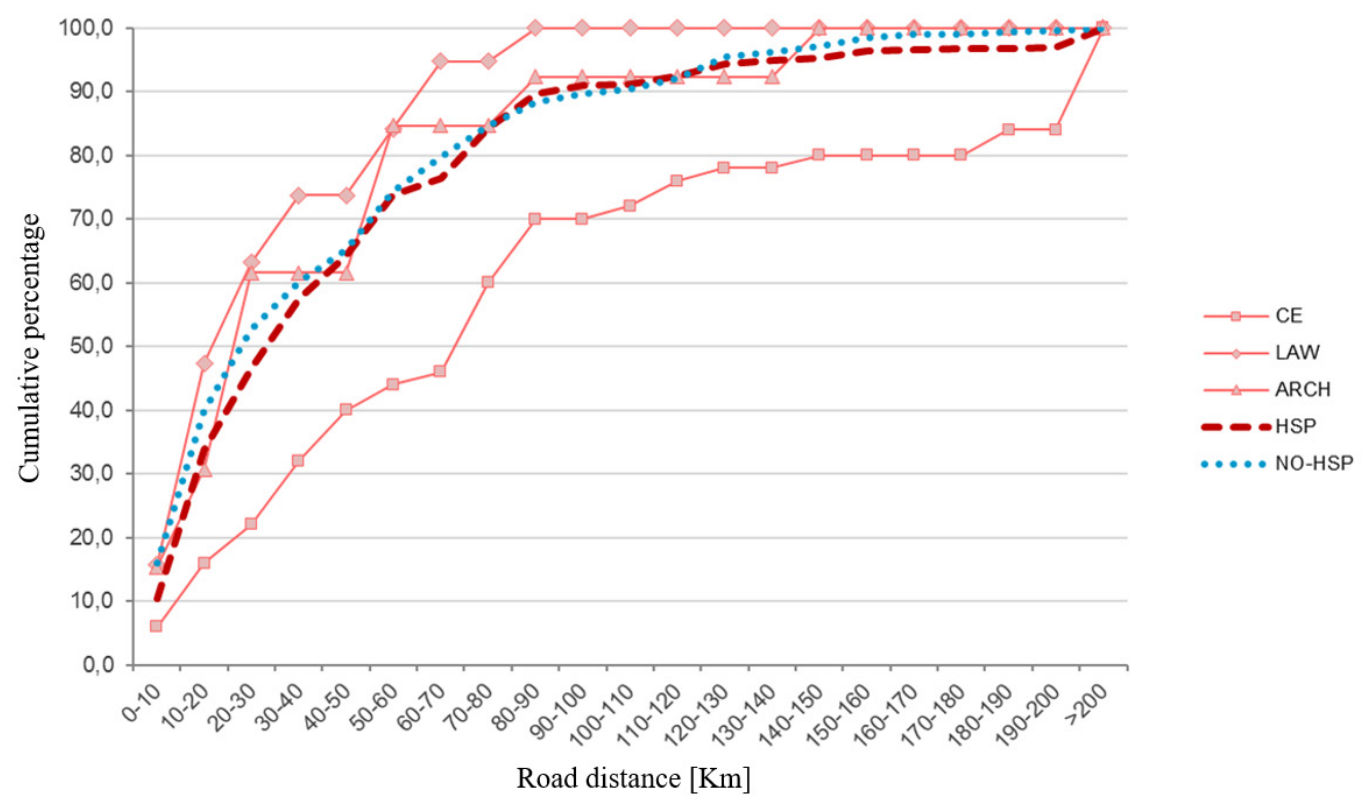

Figure 4. Cumulative distribution of commuting distances (regarding education and occupation). Source: 2012 authors' surveys

Although it is not possible to ensure that differences in commuting distances between HSPs and NHSPs are attributable to chance, the tests show statistically significant differences regarding the type of residence (according to a Kruskal-Wallis Test). Previous findings on the effect of rurality have been somewhat contradictory, partly because of the different manners in which rural has been defined (Boyle et al., 2001; Champion, 2009). For CLM, it can be concluded that workers residing in the main regional centralities commute, on average, longer distances $(56.9 \mathrm{~km}$ for those located at FUA centers and 50.3 $\mathrm{km}$ for those located at DA sub-centers) than those residing at other CLM municipalities $(36.9 \mathrm{~km})$. This finding can be explained by the greater concentration at FUA centers of HSPs, who are expected to commute longer distances (which, as previously mentioned, might be justified either by higher income levels, which can compensate for commuting costs, or by larger search areas for jobs). Nevertheless, the share of out-commuters is lower for workers residing in the main urban centralities (CLM FUA centers and DA sub-centers; slightly higher than 15\%) than for workers residing in other CLM municipalities (more rural areas; slightly more than 50\%) (see Table 1).

The tests also showed statistically significant differences regarding occupation (see Table 1). It can be concluded that although the differences are significant between CE and LAW, it is not possible to identify statistically significant differences between ARCH and the other two groups. Therefore, the economic activity sector has relevant influences on commuting distances (according to both a Tamhane and a Games-Howell tests): longer commutes are more attractive to CE (102.1 km) than to LAW (31.2 $\mathrm{km})$. For LAW, commuting is more local, and the distances are even shorter than the regional average $(50.4 \mathrm{~km})$. The notable differences with regard to occupation are also depicted in the graph (Fig. 4).

\subsection{Business travel patterns}

The third step of this paper analyses differences in the spatial organization of business travel regarding education and occupation. 


\subsubsection{Share of business travelers}

As expected, being involved in business travel was positively correlated with the level of education (see Table 1): the percentage of NHSPs undertaking business trips was only $16.4 \%$, whereas this figure doubled to $31.9 \%$ for HSPs. Moreover, the differences were statistically significant regarding occupation (see Table 1): $86.1 \%$ of LAW and $87.3 \%$ of ARCH engaged in business travel, whereas this percentage decreased to $54.5 \%$ for CE. This finding can be explained by the substantial number of freelancers among the first two professions and the large share of business trips concerning managers and executives compared to other categories (i.e., engineers) (Aguiléra et al., 2009).

\subsubsection{Business travel distance}

Although differences in commuting distances are not statistically significant with regard to education, statistical tests (see Table 1) allows for the conclusion that distances covered for business purposes are significantly affected by university education (average business travel distances were approximately 142.7 $\mathrm{km}$ for HSPs and $113.8 \mathrm{~km}$ for NHSPs). Moreover, the longer whisker on the upper box plot side suggests that there might be greater variance in business distances among the greater values since there is a greater distance from the 3rd quartile to the upper extreme than from the median to the 3rd quartile. Thus, in addition to the average business distance, which provides an insightful description of regional business travel patterns, it is necessary to evaluate the dispersion from the average and the number of business trips at different travel distances (see Fig. 5).

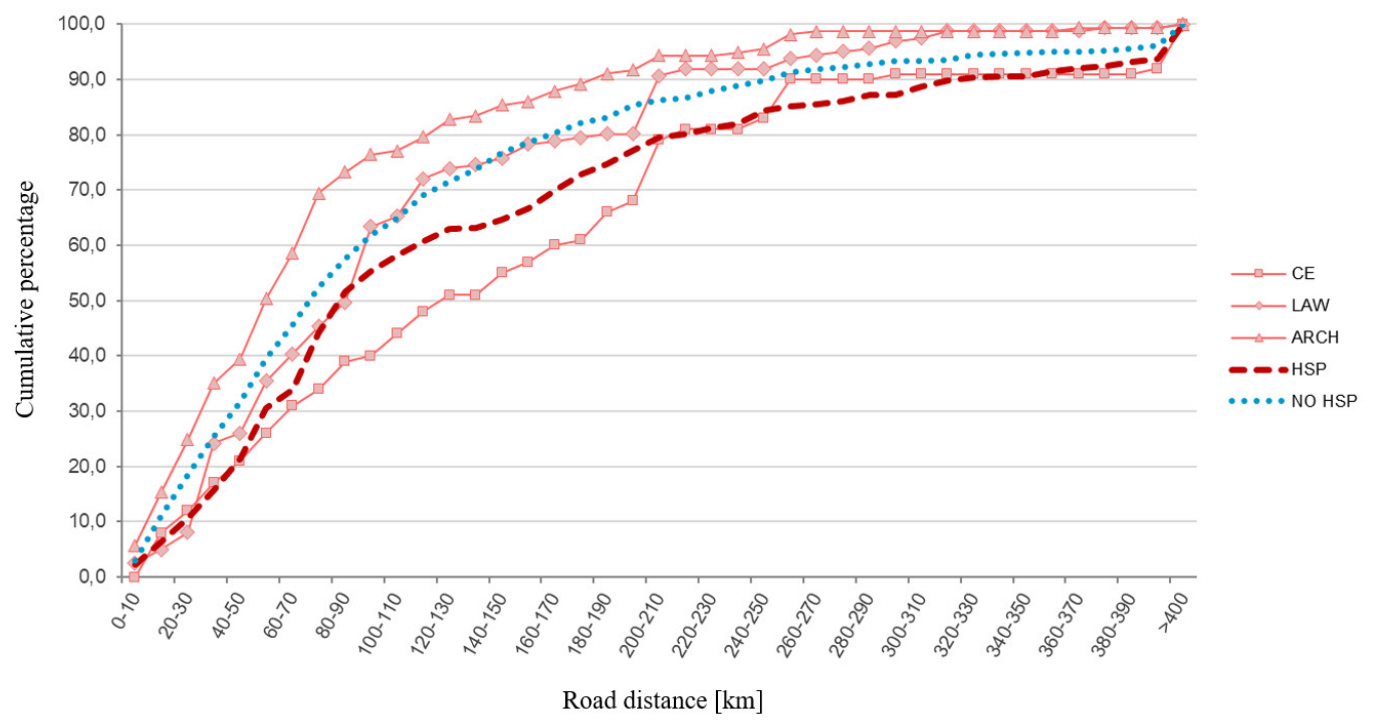

Figure 5. Cumulative distribution of business travel distances with the regard to education and occupation. Source: 2012 authors' surveys

Moreover, the tests show statistically significant differences with regard to occupation (see Table 1). Although the differences are significant between $\mathrm{CE}$ and $\mathrm{ARCH}$, it is not possible to identify statistically significant differences between LAW and the other two groups. Therefore, it is possible to conclude that the economic activity sector has a relevant influence on commuting distances (according to a Tamhane and a Games-Howell tests): longer business travel distances are more attractive to CE (200.4 km) than to $\mathrm{ARCH}(87.1 \mathrm{~km})$. 


\subsection{Concentration of workplaces: regular and non-regular (business) job locations}

In addition to the influence of employees' education and occupations on travel engagement and travel distances, attraction capabilities should be explored to grasp the complexity of the CLM urban network ("degree of interaction"/"intra-regional cohesion") and its regional openness to Madrid ("metropolitan integration") and other Spanish regions ("regional openness"). These factors are assessed considering the concentrations of, first, regular workplaces and, second, business destinations.

On the one hand, there are statistically significant differences in the regular workplace concentration with regard to education (see Table 1). Regardless of education, in 2012, there was a high percentage of regular workplaces located within CLM, indicating that the region offered a large number of opportunities to its working population: only $8.1 \%$ of NHSPs and $10.1 \%$ of HSPs commuted to other Spanish regions, including Madrid (see Fig. 6). However, when examining the complexity of the CLM urban network, it can be concluded that concentrations of highly skilled jobs at FUA centers were greater than non-highly skilled jobs (60.5\% and 48.2\%, respectively), which were concentrated more in other CLM municipalities. This notable concentration of regular workplaces at FUA centers supports the thesis of the consolidation of the CLM main urban structure as a set of centralities distributed across the rural region. Thus, for an intra-regional scale, this finding indicates a polycentric spatial organization of urban centers in CLM (more notable for qualified jobs). Smaller differences regarding education were found for regular workplaces located in the Madrid region, although the national capital (Madrid) exerted a greater influence on HSPs than on NHSPs (7.1\% and 5.3\%, respectively). This unsurprisingly greater concentration in the Madrid municipality than in other parts of the metropolitan area indicates a monocentric supra-regional spatial organization of commuting travel. Nevertheless, the attractor capabilities of the metropolitan center were outstandingly less than those of the FUA centers (5.3\% compared to $48.2 \%$, respectively, for NHSPs and $7.1 \%$ compared to $60.5 \%$ for HSPs). Finally, regardless of education, the number of regular workplaces in Spanish regions other than Madrid or CLM was very low. Overall, regional openness for commuting travel purposes was very limited for the CLM working population. 


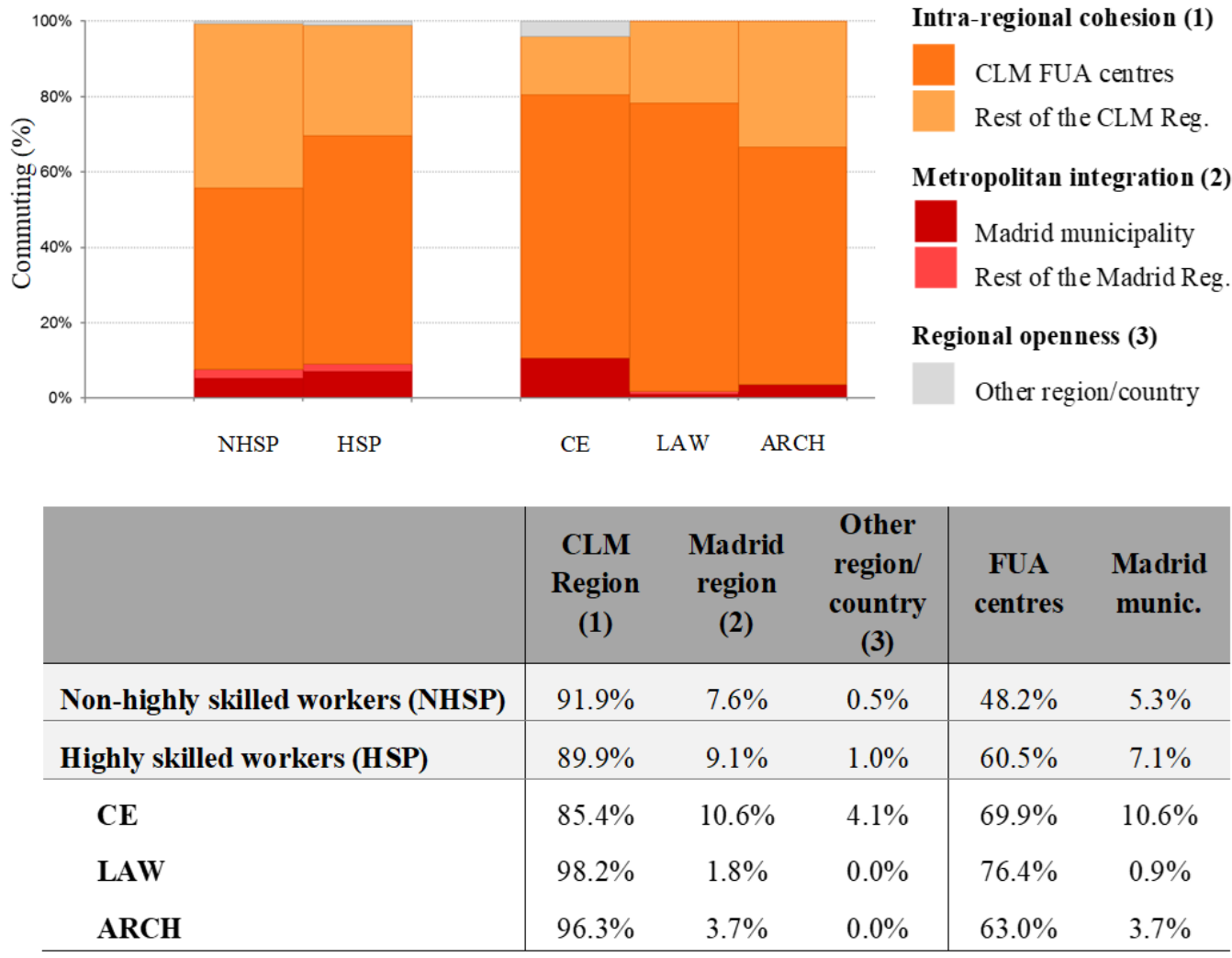

Figure 6. Concentration of regular workplace locations with regard to education and occupation. Source: 2012 authors' surveys.

Statistically significant differences in the regular workplace concentration were also found regarding occupation (see Table 1), suggesting that intra-regional cohesion, metropolitan integration and regional openness vary with job type. There was outstanding intra-regional cohesion regardless of occupation, but this figure was slightly lower for $\mathrm{CE}$ ( $85.4 \%$ in contrast to $98.2 \%$ for LAW and $96.3 \%$ for ARCH), with FUA centers concentrating a high percentage of highly skilled jobs (more than 60\%) (see Fig. 6). In particular, for $\mathrm{CE}$, the attractor role of the Madrid municipality was key compared to the other two occupations (10.6\% for CE, $0.9 \%$ for LAW and 3.7\% for ARCH). This finding indicates a greater metropolitan integration of CE commuting travel patterns than those of LAW and ARCH. Finally, only $\mathrm{CE}$ considered establishing their regular workplaces in other Spanish regions (although this openness of commuting travel patterns was very low compared to their metropolitan integration and, to a greater extent, to their intra-regional cohesion).

In contrast, there were statistically significant differences in business destinations with regard to education (see Table 1). First, although a significant proportion of business travel occurred within CLM (with an outstanding concentration at FUA centers), this intra-regional cohesion was slightly greater for NHSPs than for HSPs (57.9\% and 51.5\%, respectively) (see Fig. 7). Conversely, metropolitan integration of business travel was somewhat similar for HSPs and for NHSPs, with the Madrid municipality playing a dominant concentration role (greater for HSPs). This predictable greater concentration in the Madrid municipality than in other parts of the metropolitan area indicates a monocentric supra- 
regional spatial organization of business travel. The similar attraction of the Madrid municipality and FUA centers regardless of education is notable. Finally, business travel to other Spanish regions was of considerable magnitude (although slightly lower for NHSPs than for HSPs, indicating that regional openness increases with education).

Statistically significant differences in business destinations were also found with regard to occupation (see Table 1). There was outstanding intra-regional cohesion regardless of occupation, with FUA centers concentrating a high percentage of business destinations, but this figure was slightly lower for CE: $54.5 \%$ for CE, $66.5 \%$ for LAW and $75.0 \%$ for ARCH (see Fig. 7). The attractor role of the Madrid region was also noteworthy regardless of occupation (although lower for $\mathrm{ARCH}$ than for $\mathrm{CE}$ and LAW), with the metropolitan center playing a key role. This finding indicates, once again, monocentric supra-regional spatial organization of business travel regardless of occupation. These business attractor capabilities of the metropolitan center were of comparable importance to those of FUA centers for CE and $\mathrm{ARCH}$, although they were lower for LAW. Finally, the greater regional openness for business travel purposes for CE (16.8\%) than for the other two types of HSPs (5.5\% for LAW and 4.4\% for ARCH) was notable.

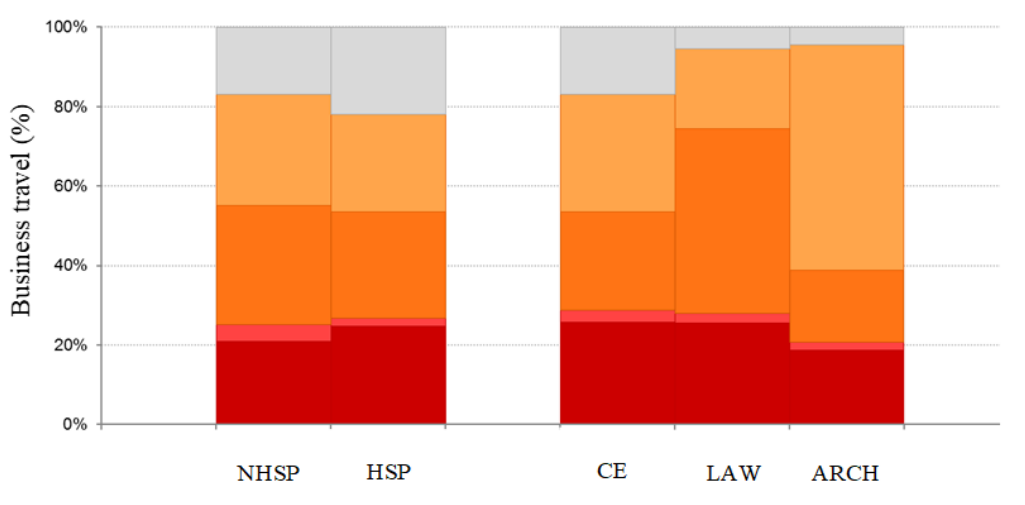

Intra-regional cohesion (1)

CLM FUA centres

Rest of the CLM Reg.

Metropolitan integration (2)

Madrid municipality

Rest of the Madrid Reg.

Regional openness (3)

Other region/country

\begin{tabular}{c|ccc|cc} 
& $\begin{array}{c}\text { CLM } \\
\text { Region } \\
(\mathbf{1})\end{array}$ & $\begin{array}{c}\text { Madrid } \\
\text { region } \\
(\mathbf{2})\end{array}$ & $\begin{array}{c}\text { Other } \\
\text { region/ } \\
\text { country } \\
(3)\end{array}$ & $\begin{array}{c}\text { FUA } \\
\text { centres }\end{array}$ & $\begin{array}{c}\text { Madrid } \\
\text { munic. }\end{array}$ \\
\hline Non-highly skilled workers (NHSP) & $57.9 \%$ & $25.1 \%$ & $17.0 \%$ & $29.9 \%$ & $20.9 \%$ \\
\hline Highly skilled workers (HSP) & $51.5 \%$ & $26.7 \%$ & $21.9 \%$ & $26.8 \%$ & $24.7 \%$ \\
\hline CE & $54.5 \%$ & $28.7 \%$ & $16.8 \%$ & $24.8 \%$ & $25.7 \%$ \\
LAW & $66.5 \%$ & $28.0 \%$ & $5.5 \%$ & $46.3 \%$ & $25.6 \%$ \\
ARCH & $75.0 \%$ & $20.6 \%$ & $4.4 \%$ & $18.1 \%$ & $18.8 \%$ \\
\hline
\end{tabular}

Figure 7. Concentration of non-regular workplace (business destinations) with regard to education and occupation. Source: 2012 authors' surveys

\section{Discussion}

Much has been written regarding the spatial configurations of functional linkages, but two main gaps can be identified in the existing literature. First, most studies have analyzed commuting independent of business travel behavior. Second, studies have focused mainly on large global cities, urban regions and 
international relations and have paid little attention to rural or sparsely populated regions. In an attempt to fill these gaps, this paper analyses commuting and business travel spatial organizations for workers residing within a low-density rural region influenced by metropolitan processes (called rural metroadjacent regions), paying special attention to differences in workers' education levels and job types. The relevance of engaging with these rural regions relates to the multiple transformations (including population growth, changing production, dynamics, the integration of the rural dimension into national society, the cultural dimension, the role of the state, and the social and political role of particular actors) they have witnessed in recent years. First, a rural population renaissance ("urban-rural shift," "turnaround" or "counterurbanization") has been occurring since the 1960s in the United States and Western Europe (Renkow \& Hoover, 2000). Second, there is a rural commuting reconfiguration (Green \& Meyer, 1997; Mitchell, 2005 ). In this sense, rural regions adjacent to metropolitan areas are an especially interesting research topic because they are hybrid territories that are neither fully integrated into metropolitan dynamics nor totally rural and self-contained. However, this research was motivated not only by the increasing dynamism of these rural regions but also by the polycentric urban configurations that have been emerging during the last decades in the most highly urbanized parts of the world (and that have started to absorb medium-sized cities in nearby rural territories).

The main contribution of this paper is twofold. On the one hand, from a theoretical point of view, the relevance of this paper is that it sheds light on these regions' urban structure and whether a reconfiguration process has occurred during the last decades. In this regard, the paper stimulates further discussion on the accuracy of different functional linkages when explaining the underlying urban network, in line with Burger et al.'s (2014) suggestions that different spatial organizations could result from the types of functional relations considered and individuals' characteristics. In other words, is the urban network reconfiguration already identified within rural metro-adjacent regions (from a leaderless model to an incipient polycentric one) and occurring regardless of the functional linkages analyzed? Does a region have great metropolitan dependence based on the analysis of one type of functional linkage but a more internal cohesion based on another type of functional linkage? Are the regional spatial interaction patterns influenced by individual characteristics? These results may help rural metro-adjacent territories to elaborate their policies and regional plans, seeking more supra-regional interdependencies with the metropolitan region, contributing to blurring the historical rural-urban dichotomy, or consolidating intra-regional cohesion. On the other hand, from a methodological point of view, this paper suggests an alternative to traditional censuses to collect travel behavior. This is especially relevant in rural regions or territories with lower economic opportunities.

Overall, the analyses developed here produced revealing outcomes. The first general (and predictable) conclusion extracted from the analyses reinforces the idea of the consolidation of a polycentric spatial organization (hypothesis 1) of urban centers in rural metro-adjacent areas (although concluded for the CLM region and in accordance with Mohino et al. (2017) and Pillet et al. (2014), similar configurations could be identified in other regions around the world). This outcome is evidenced by three processes. First, there is outstanding residential concentration in a set of centralities distributed across the rural region (increasing with education). Second, there is an important concentration of regular workplaces at FUA centers, meaning that commuting mainly occurs within the limits of the region, although metropolitan integration for commuting travel purposes is slightly greater for HSPs. This could indicate that HSPs employed in the metropolitan region are more attracted by the idea of locating/maintaining their residences in rural areas and taking advantage of certain amenities and quality of life (pollution, noise, congestion or land price issues are less relevant in these rural metro-adjacent regions than closer to the metropolitan center). Third, a significant proportion of business travel occurs within CLM (with an outstanding concentration at FUA centers), suggesting the conclusion of an intra-regional polycentric 
urban structure (although in this case, the similar attraction of the Madrid municipality and FUA centers, regardless of education, is notable).

The second finding extracted from the analyses shows that, similar to previous conclusions regarding urban regions, the type of functional relationship (commuting vs business travel), educational level and job type also had impacts on rural metro-adjacent region travel patterns (hypotheses 2 and 3). First, the level of engagement in both commuting and business travel increased with education, possibly due to the often better-paid jobs for highly educated workers, which can compensate commuting costs (however, differences between professionals increase for business travel). Moreover, although the level of engagement for HSPs was similar for commuting and business travel, as could be expected, fewer NHSPs travelled for business purposes than for commuting. Second, the travel distances revealed differences between commuting and business travel patterns. The comparison between different types of travel and their relationships with education levels showed that business travel occurs over longer distances than commuting for all workers residing in rural metro-adjacent regions regardless of education. This finding is in accordance with Burger et al. (2014), who found a much more local geographical scope of commuting than business travel. Additionally, although the differences in commuting distance with regard to education were not statistically significant, the analyses allowed us to conclude that the distances covered for business purposes were significantly positively affected by education.

In summary, the comparison between rural metro-adjacent regions' commuting and business travel patterns revealed relevant conclusions regarding the spatial configuration of this rural metro-adjacent region, which differed in terms of the considered functional linkage. On the one hand, commuting travel patterns showed a highly polycentric regional configuration and a weak regional openness (although with a noteworthy interaction with the metropolitan center). On the other hand, business travel patterns showed a polycentric regional configuration (weaker than for commuting) and a relevant regional openness (with a noteworthy interaction with the metropolitan center).

\section{Acknowledgements}

This work was supported by the Spanish National Research Plan [CSO2015- 63815-R], the Juan de la Cierva Formación Fellowship [FJCI-2015-25826], the José Castillejo Travel Grant [CAS16/00140] and the Research Project "Dinámicas urbanas: una aproximación morfológica y funcional. Interrelaciones entreconfiguración urbana, movilidad y actividades económicas” [CGT180016] 


\section{References}

Aguilera, A. (2005). Growth in commuting distances in French Polycentric metropolitan areas: Paris, Lyon and Marseille. Urban Studies, 42(9), 1537-1547.

Aguiléra, A. (2008). Business travel and mobile workers. Transportation Research A, 42, 1109-1116.

Aguiléra, A., Massot, M. H., \& Proulhac, L. (2009). Exploring the relationship between work and travel behavior on weekdays. An analysis of the Paris Region Travel Survey over 20 years. Transportation Research Record, 2135, 69-77.

Aguilera, A., \& Proulhac, L. (2015). Socio-occupational and geographical determinants of the frequency of long-distance business travel in France. JTRG, 43, 28-35.

Albertos, J. M., Noguera, J., Pitarch, M. D., \& Salom, J. (2007). La movilidad diaria obligada en la Comunidad Valenciana entre 1991 y 2001: Cambio territorial y nuevos procesos. Cuadernos de Geografía, 81-82, 93-118.

Beaverstock, J. V., Derudder, B. Faulconbridge, J., \& Witlox, F. (Eds). (2010). International business travel in the global economy. Farnham, England: Ashgate.

Bernard, J., Kostelecký, T., \& Patočková, V. (2014). The innovative regions in the Czech Republic and their position in the international labor market of highly skilled workers. Regional Studies, 48(10), 1691-1705.

Bijker, R. A., Haartsen, T, \& Strijker, D. (2015). How people move to rural areas: Insights in the residential search process from a diary approach. Journal of Rural Studies, 38, 77-88.

Blumen, O. (1994). Gender differences in the journey to work. Urban Geography, 15(3), 223-245.

Boarnet, M. G., \& Sarmiento, S. (1998). Can land-use policy really affect travel behavior? A study of the link between non-work travel and land-use characteristics. Urban Studies, 35(7), 1155-1169.

Boyle, P., Cassidy, S., Duke-Williams, O., Rees, P., Stokes, G. \& Turner, A. (2001). Commuting patterns in rural areas. Cheltenham, England: Countryside Agency.

Brown, B. \& O'Hara, K. (2003). Place as a practical concern of mobile workers. Environment and Planning A, 35,1565-1587.

Burger, M. J, de Goei, B., van der Laan, L., \& Huisman, F. J. M. (2011). Heterogeneous development of metropolitan spatial structure: Evidence from commuting patterns in English and Welsh cityregions, 1981-2001. Cities, 28, 160-170.

Burger, M. J, Meijers, E., \& van Oort., F. G. (2014). Multiple perspectives on functional coherence: Heterogeneity and multiplexity in the Randstad. Tijdschriftvoor Economischeen Sociale Geografie, 105(4), 444-464.

Cebrián, F., \& Cebrián, A. (2000). Los desequilibrios en la estructura urbana de Castilla La Mancha. Papeles Geografia, 32, 42-59.

Cervero, R., \& Kockelman, K. (1997). Travel demand and the 3Ds: density, diversity, and design. Transportation Research D, 3, 199-219.

Champion, A. G. (2001). A changing demographic regime and evolving polycentric urban region: Consequences for the size, composition and distributions of city populations. Urban Studies, 38, 657-677.

Champion, T. (2009). Urban-rural differences in commuting in England: A challenge to the rural sustainability agenda? Planning Practice \& Research, 24(2), 161-183.

Champion, T., Coombes, M., \& Brown, D. L. (2009). Migration and longer-distance commuting in rural England, Regional Studies, 43(10), 1245-1259.

Clark, W. A. V., \& Kuijpers-Linde, M. (1994). Commuting in restructuring urban regions. Urban Studies, 3, 465-483. 
Dargay, J. M., \& Stephen, C. (2012). The determinants of long distance travel in Great Britain. Transportation Research Part A: Policy and Practice, 46, 576-587.

De Goei, B., Burger, M., van Oort, F., \& Kitson, M. (2010). Functional polycentrism and urban network development in the greater south east UK: Evidence from commuting patterns. Regional Studies, 44, 1149-1170.

Derudder, B., Devriendt, L., van Nuffel, N.,\& Witlox, F. (2010). Geographies of business air travel in Europe. In J. V. Beaverstock, J. B. Derudder, J. Faulconbridge, \& F. Witlox (Eds). International business travel in the global economy (pp. 31-56). Farnham, England: Ashgate.

Denstadli, J., Julsrud, T., \& Hjorthol, R. (2012). Videoconferencing as a mode of communication: A comparative study of the use of videoconferencing and face-to-face meetings. Journal of Business \& Technical Communication, 26(1), 65-91.

Derudder, B., Hoyler, M., Taylor, P., \& Witlox, F. (2012). International handbook of globalization and world cities. Cheltenham, England: Edward Elgar.

Dieleman, F. M., Dijst, M., \& Burghouwt, G. (2002). Urban form and travel behavior: Micro-level household attributes and residential context. Urban Studies, 39, 507-527.

Dieleman, F., \& Faludi, A. (1998). Randstad. Rhine-Ruhr and Flemish Diamond as one polynucleated macro-region? Tijdschriftvoor Economische en Sociale Geograie, 89, 320-327.

ESPON. (2006). Urban-rural relations in Europe (final report). Helsinki: Center for Urban \& Regional Studies, Helsinki Univ. of Technology.

Faulconbridge, J. R., Beaverstock, J., Derudder, B., \& Witlox, F. (2009). Corporate ecologies of business travel in professional service firms: Working towards a research agenda. EURS, 16(3), 295-308.

Figueroa, M. J., Nielsen, T. A. S., \& Siren, A. (2014). Comparing urban form correlations of the travel patterns of older and younger adults. Transport Policy, 35, 10-20.

Findlay, A., Stockdale, A., Findlay, A., \& Short, D. (2001). Mobility as a driver of change in rural Britain: An analysis of the links between migration, commuting and travel to shop patterns. International Journal of Population Geography, 7(1), 1-15.

Florida, R., Gulden, T., \& Mellander, C. (2008). The rise of the mega-region, Cambridge J. Regions, Economy \& Society, 1, 459-476.

Frändberg, L., \& Vilhelmson, B. (2011). More or less travel: Personal mobility trends in the Swedish population focusing gender and cohort. JTRG, 19(6), 1235-1244.

Gallo, M. T., Garrido, R., \& Vivar, M. (2010). Cambios territoriales en la Comunidad de Madrid: Policentrismo y dispersion. EURE, 36(107), 49-65.

García-Palomares, J. C. (2008). Incidencia en la movilidad de los principales factores de un modelo metropolitano cambiante, EURE, 34(101), 5-24.

García-Palomares, J. C. (2010). Urban sprawl and travel to work: The case of the metropolitan area of Madrid. JTRG, 18, 197-213.

Garmendia, M. (2008). Cambios en la estructura urbana y territorial facilitados por la alta velocidad ferroviaria. La línea Madrid-Sevilla a su paso por la provincia de Ciudad Real. Thesis dissertation. CR: UCLM.

Garmendia, M., Ureña, J. M., \& Coronado, J. M. (2011). Cambios en la estructura territorial debidos a nuevas conexiones de alta velocidad en territorios aislados: La provincia de Ciudad Real en España. EURE, 37(110), 89-115.

Giuliano, G., \& Dargay, J. (2006). Car ownership, travel and land use: A comparison of the US and Great Britain. Transport. Research A, 40, 106-124.

Giuliano, G., \& Small, K. A. (1993). Is the journey to work explained by urban structure? Urban Studies, 9, 1485-1500. 
Giuliano, G., \& Gillespie, A. (1997). Research issues regarding societal change and transport. JTRG, 5(3), 165-176.

Green, A. E., Hogarth, T., \& Shackelton, R. E. (1999). Longer distance commuting as a substitute for migration in Britain: A review of trends and implications. International Journal of Population Geography, 5(1), 49-67.

Grimes, S. (2000). Rural areas in the information society: Diminishing distance or increasing learning capacity? Journal of Rural Studies, 16(1), 13-21.

Gordon, P., Kumar, A., \& Richardson, H. W. (1989) Gender differences in metropolitan travel behavior. Regional Studies, 23(6), 499-510.

Gustafson, P. (2012). Managing business travel: Developments and dilemmas in corporate travel management. Tourism Management, 33, 276-284.

Hall, P., \& Pain, K. (2006). The polycentric metropolis. London: Earthscan.

Hanson, S., \& Johnston, I. (1985). Gender differences in work trip lengths: Implications and explanations. Urban Geography, 6(3),193-219.

Harris, S., Alasia, A., \& Bollman, R. D. (2008). Rural commuting: Its relevance to rural and urban Labor markets. Rural and Small Town Canada Analysis Bulletin, 7(6). Catalogue No. 21-006-XIE. Ottawa: Statistics Canada.

Harsman, B., \& Quigley, J. (1988). Education, job requirements and commuting: An analysis of network flows. In M. J. Beckman, B. Johansson, F. Snickars, and R. Thord (Eds.). Knowledge and networks in a dynamic economy (pp. 261-272). Berlin/Heidelberg: Springer-Verlag.

Haselkorn M., Spyridakis, J., Conquest, L, \& Barfield, W. (1989). Surveying commuter behavior as a basis for designing motorist information systems. Paper presented at the First Vehicle Navigation and Information Systems Conference, IEEE, Toronto, Canada. Retrieved from http://ieeexplore.ieee. org/stamp/stamp.jsp?arnumber $=98746$

Hermelin, B., \& Trygg, K. (2012). New geographies of work: A case study from Sweden. Urbaniizziv, 23(1),126-134.

Hincks, S., \& Wong, C. (2010). The spatial interaction of housing and labor markets: Commuting flow analysis of North West England. Urban Studies, 47(3), 620-649.

Huber, P. (2014). Are commuters in the EU better educated than non-commuters but worse than migrants? Urban Studies, 51(3), 509-525.

INE. (1981). Censo de Población y Viviendas 1981. Madrid: INE.

INE. (2011). Censo de Población y Viviendas 2011. Madrid: INE.

Jara-Díaz, S. R., \& Videla, J. (1989). Detection of income effect in mode choice: Theory and application. Transportation Research Part B, 23(6), 393-400.

Jones, A. (2013). Conceptualizing business mobilities: Towards an analytical framework. Research in Transportation Business \& Management, 9, 58-66.

Kakihara, M., \& Sørensen, C. (2004). Practicing mobile professional work: Tales of locational, operational, and interactional mobility. The Journal of Policy, Regulation and Strategy for Telecommunication, Information and Media, 6(3), 180-187.

Kilpatrick, S., Johns, S., Vitartas, P., Homisan, M. (2011). Mobile skilled workers: Making the most of an untapped rural community resource. Journal of Rural Studies, 27,181-190.

Kim, C, Sang, S., Chun, Y., \& Lee, W. (2012). Exploring urban commuting imbalance by jobs and gender. Applied Geography, 32, 532-545.

Kloosterman, R. C., \& Musterd, S. (2001). The polycentric urban region: Towards a research agenda, Urban Studies, 38, 623-633.

Kwan, M. P. (1999). Gender, the home-worklink, and space-time patterns of non-employment activities. Economic Geography, 75(4), 370-394. 
Lee, B. S., \& McDonald, J. F. (2003). Determinants of commuting time and distance for Seoul residents: The impact of family status on the commuting of women. Urban Studies, 40(7), 1283-1320.

Limtanakool, N., Dijst, M., \& Schwanen, T. (2005). On the participation in medium- and long-distance travel: A decomposition analysis for the UK and the Netherlands. Tijdschriftvoor Economische and Sociale Geografie, 97(4), 389-404.

Limtanakool, N., Dijst, M., \& Schwanen, T. (2007). A Theoretical framework and methodology for characterizing national urban systems on the basis of flows of people: Empirical evidence for France and Germany. Urban Studies, 44(11), 2123-2145.

Limtanakool, N., Dijst, M., \& Schwanen, T. (2009). Developments in the Dutch urban system on the basis of flows. Reg. Studies, 43(2),179-196.

Lowe, J. C. (1998). Patterns of spatial dispersion in metropolitan commuting. Urban Geography, 19(3), $232-253$.

Lyons, G., \& Chatterjee, K. (2008). A human perspective on the daily commute: Costs, benefits and trade-offs. Transport Reviews, 28(2), 181-198.

Lyons, G. (2013). The social practices surrounding meetings. Research in Transportation Business and Management, 9, 50-57.

Malmberg, G. (1997). Time and space in international migration. In T. Hammar, G. Brochmann, K. Tamas \& T. Faist (Eds.) International migration, immobility and development: Multidisciplinary Perspectives (pp.1-19). NY: Berg.

Manaugh, K., Miranda-Moreno, L. F., \& El-Geneidy, A. M. (2010). The effect of neighborhood characteristics, accessibility, home-work location, and demographics on commuting distances. Transportation, 37(4), 627-646.

Martínez-García, E., Ferrer-Rosell, B., \& Coenders, G. (2012). Profile of business and leisure travelers on low cost carriers in Europe. Journal of Air Transport Management, 20,12-14.

Mason, K. J. (2002). Future trends in business travel decision making. Journal of Air Transportation, $7(1), 47-68$.

Milbourne, P. (2007). Re-populating rural studies: Migrations, movements and mobilities. Journal of Rural Studies, 23(3), 381-386.

Milbourne, P., \& Kitchen, L. (2014). Rural mobilities: Connecting movement and fixity in rural places. Journal of Rural Studies, 34, 326-336.

Millard-Bell, A., \& Schipper, L. (2011). Are we reaching peak travel? Trends in passenger transport in eight industrialized countries. Transport. Reviews, 31(3), 357-378.

Mohino, I, Ureña, J. M., \& Solis, E. (2016). Transport infrastructure and territorial cohesion in rural metro-adjacent regions: A multimodal accessibility approach. The case of Castilla-La Mancha in the context of Madrid (Spain). JTRG, 57, 115-133.

Mohino, I., Solis, E., \& Ureńa, J. M. (2017). Changing commuting patterns in rural metro-adjacent regions: The case of Castilla-La Mancha in the context of Madrid, Spain. Regional Studies, 51(7), $1115-1130$.

Naess, P. (2006). Accessibility, activity participation and location of activities: Exploring the links between residential location and travel behavior. Urban Studies, 43(3), 627-652.

Nelson, D., \& Niles, J. (2000). Observations on the causes of non-work travel growth. 79th Meeting of the Transportation Research Board, January 9-13, Washington, DC.

OECD. (2011). Defining and describing regions, in OECD regions at a glance 2011. Retrieved from http://dx.doi.org/10.1787/reg_glance-2011-4-en

Öhman, M., \& Lindgren, U. (2003). Who is the long-distance commuter? Patterns and driving forces in Sweden. Cybergeo: European Journal of Geography, 243. Retrieved from http://cybergeo.revues. org/4118 
Ortiz-Guerrero, C. E. (2013). The new regionalism. Policy implications for rural regions. Cuadernos Desarrollo Rural, 10(70), 47-67.

Parr, J. B. (2005). Perspectives on the city-region. Regional Studies, 39, 555-566.

Pinjari, A. R., Pendyala, R. M., Bhat, C. R., \& Waddell, P.A. (2007). Modeling residential sorting effects to understand the impact of the built environment on commute mode choice. Transportation, 34, 557-573.

Pillet, F., Cañizares, M. C. , Ruiz, A. R., Martinez, H. S., Plaza, J., Santos, J. F. (2014). Applying the European spatial development perspective in low-density regions: A methodology based on mobility and labor market structure. Urban Studies, 51(3), 577-595.

Piorr, A., Ravetz, J., \& Tosics. I. (2011). Peri-urbanization in Europe: Towards a European policy to sustain urban-rural futures. Copenhagen: University of Copenhagen, Academic Books Life Sciences.

Prashker, J., Shiftan Y., \& Hershkovitch-Sarusi, P. (2008). Residential choice location, gender and the commute trip to work in Tel Aviv. JTRG, 16, 332-341.

Punpuing, S. (1993) Correlates of commuting patterns: A case-study of Bangkok, Thailand. Urban Studies, 30(3), 527-546.

Ramli, M. I., Oeda, Y., Sumi, T., \& Matsunaga, C. (2011). Accommodating flexible daily temporal constraint on a continuous choice model of departure time for urban shopping travel. International Journal of Urban Sciences, 15, 215-233.

Räsänen, M., Moberg A., Picha, M., \& Borggren, C. (2010). Meeting at a distance: Experiences of media companies in Sweden. Technology in Society, 32, 264-273.

Ravetz, J., Fertner, C., \& Sick-Nielsen, T. (2013). The dynamics of periurbanization. In K. Nilsson, S. Pauleit, S. Bell, C. Aalbers, \& T. A. Sick-Nielsen (Eds.), Peri-urban futures: Scenarios and models for land use change in Europe (pp. 1344). The Netherlands: Springer.

Renkow, M., \& Hoover, D. (2000). Commuting, migration, and rural-urban population dynamics. J. Reg. Science, 40(2), 261-287.

Rouwendal, J., \& Rietveld, P. (1994). Changes in commuting distances of Dutch households. Urban Studies, 31(9), 1545-1557.

Russo, G., Teschi, F. Reggiani, A., \& Nijkamp, P. (2014). Commuter effects on local labor markets: A German modelling study. Urban Studies, 51(3), 493-508.

Sandow, E. (2008). Commuting behavior in sparsely populated areas: Evidence from northern Sweden. JTRG, 16, 14-27.

Sandow, E., \& Westin, K. (2010). Preferences for commuting in sparsely populated areas. The case of Sweden. Journal of Transport and Land Use, 2(3/4), 87-107.

Sassen, S. (1999). Globalization and its discontents: Essays on the new mobility of money and people. NY: Free Press.

Schofer, J. L. (2002-June). National Household Travel Survey, letter report to the Committee to Review the Bureau of Transportation Statistics Survey Programs. In Measuring Personal Travel and Goods Movement: A Review of the Bureau of Transportation Statistics' Surveys—Special Report 277 (2003), (pp. 54-78). Washington, DC: The National Academies Press. https://doi.org/10.17226/10837.

Schwanen, T., Dieleman, F. M., \& Dijst. M. (2001). Travel behavior in Dutch monocentric and polycentric urban systems. JTRG, 9, 173-186.

Sick-Nielsen, T. A., \& Harder Hovgesen, H. (2008). Exploratory mapping of commuter flows in England and Wales. Journal of Transport Geography, 16, 90-99.

Singell, L., \& Lillydahl, J. (1986). An empirical analysis of the commute to work patterns of males and females in two-earner households. Urban Studies, 2, 119-129.

Sioui, L., Morency, C., \& Trepanier, M. (2013). How car-sharing affects the travel behavior of house- 
holds: A case study of Montreal, Canada. International Journal of Sustainable Transportation, 7, 52-69.

Solis, E., Ureña, J. M., \& Ruiz-Apilánez, B. (2012). Transformación del sistema urbano-territorial en la región central de la España peninsular: La emergencia de la región metropolitana policéntrica madrileña. Scripta Nova, 16. Retrieved from http://revistes.ub.edu/index.php/ScriptaNova/article/ view/ 14782

Solis, E., Mohino, I., \& Ureña, J. M. (2014). Global metropolitan-regional scale in evolution: Metropolitan intermediary cities and metropolitan cities. EPS, 23(3), 568-596.

Stockdale, A. (2006). Migration: Pre-requisite for rural economic regeneration? Journal of Rural Studies, 22, 354-366.

Stopher, P., Greaves, S., \& Xu, M. (2005). Using national data to simulate metropolitan area household travel data. Journal of Transportation and Statistics, 8(3), 83-95.

Sultana, S. (2002). Job/housing imbalance and commuting time in the Atlanta metropolitan area: Exploration of causes of longer commuting time. Urban Geography, 23(8), 728-749.

Susilo, Y. O., \& Maat, K. (2007). The influence of built environment to the trends in commuting journeys in the Netherlands. Transportation, 34, 589-609.

Titheridge, H., \& Hall, P. (2006). Changing travel to work patterns in South East England. JTRG, 14, $60-75$.

Trendle, B., \& Siu, J. (2005). Commuting patterns of Sunshine Coast residents and the impact of education. Australasian Journal of Regional Studies, 13(2), 221-230.

Ureña, J. M., \& Muruzábal, J. J. (2006). Sostenibilidad y eficiencia económica en el transporte de la Comunidad de Madrid: Evolución de la última década. Revista del Instituto de Estudios Económicos $1 \& 2,191-222$.

van Acker, V., \& Witlox, F. (2011). Commuting trips within tours: How is commuting related to land use? Transportation, 38, 465-486.

van de Coevering, P., \& Schwanen, T. (2006). Re-evaluating the impact of urban form on travel patterns in Europe and North-America. Transport Policy, 13(3), 229-239.

van Winden, W., van den Berg, L., \& Pol, P. (2007). European Cities in the knowledge economy: Towards a typology. Urban Studies, 44(3), 525-549.

Verhoeven, M., Arentze, T. A., Timmermans, H. J. P., \& van der Waerden, P. (2007). Examining temporal effects of lifecycle events on transport mode choice decisions. International Journal of Urban Sciences, 11, 1-13.

Wang, F. (2001). Explaining intraurban variations of commuting by job accessibility and workers' characteristics. EPB, 28, 169-182.

Watts, M. J. (2009). The impact of spatial imbalance and socioeconomic characteristics on average distance commuted in the Sydney Metropolitan area. Urban Studies, 46, 317-339.

White, M. J. (1986). Sex differences in urban commuting pattern. American Economic Review, 75(2), $368-372$.

\section{Appendix}

Appendix available as a supplemental file at www.jtlu.org/index.php/jtlu/article/view/1219. Supplementary files are located under "Article Tools" on the lower right side of the web page. 